\title{
Correction to: Existence, iteration procedures and directional differentiability for parabolic QVIs
}

\author{
Amal Alphonse ${ }^{1} \cdot$ Michael Hintermüller $^{1} \cdot$ Carlos N. Rautenberg ${ }^{2}$ \\ Published online: 10 July 2021 \\ (c) Springer-Verlag GmbH Germany, part of Springer Nature 2021
}

\section{Correction to: Calc. Var. (2020) 59:95 https://doi.org/10.1007/s00526-020-01732-6}

The article "Existence, iteration procedures and directional differentiability for parabolic QVIs" written by Amal Alphonse, Michael Hintermüller, Carlos N. Rautenberg was originally published Online First without Open Access. After publication in volume 59, issue 3, article 95 the author decided to opt for Open Choice and to make the article an Open Access publication. Therefore, the copyright of the article has been changed to () The Author(s) 2020 and the article is forthwith distributed under the terms of the Creative Commons Attribution 4.0 International License, which permits use, sharing, adaptation, distribution and reproduction in any medium or format, as long as you give appropriate credit to the original author(s) and the source, provide a link to the Creative Commons licence, and indicate if changes were made. The images or other third party material in this article are included in the article's Creative Commons licence, unless indicated otherwise in a credit line to the material. If material is not included in the article's Creative Commons licence and your intended use is not permitted by statutory regulation or exceeds the permitted use, you will need to obtain permission directly from the copyright holder. To view a copy of this licence, visit http://creativecommons.org/licenses/by/4.0. Open access funding enabled and organized by Projekt DEAL.

The original article has been corrected.

Publisher's Note Springer Nature remains neutral with regard to jurisdictional claims in published maps and institutional affiliations.

The original article can be found online at https://doi.org/10.1007/s00526-020-01732-6.

Amal Alphonse

amal.alphonse@wias-berlin.de

Michael Hintermüller

michael.hintermueller@wias-berlin.de

Carlos N. Rautenberg

crautenb@gmu.edu

1 Weierstrass Institute, Mohrenstrasse 39, 10117 Berlin, Germany

2 Department of Mathematical Sciences, George Mason University, Fairfax, VA 22030, USA 